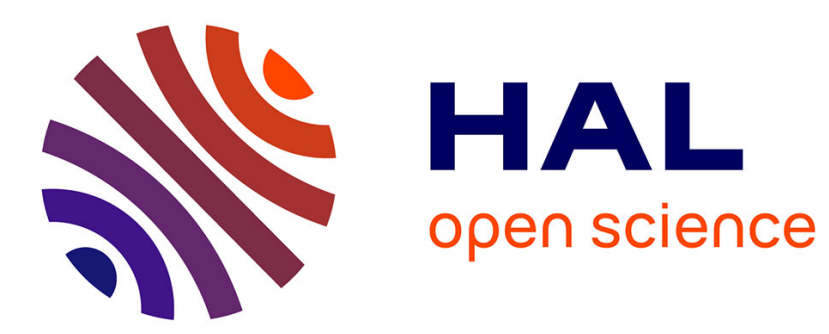

\title{
Composition of cell walls from cotyledons of pisum sativum, vicia faba and glycine max
}

\author{
J.M. Brillouet, Bernard B. Carré
}

\section{To cite this version:}

J.M. Brillouet, Bernard B. Carré. Composition of cell walls from cotyledons of pisum sativum, vicia faba and glycine max. Phytochemistry, 1983, 22 (4), pp.841-847. hal-02721215

\section{HAL Id: hal-02721215 \\ https://hal.inrae.fr/hal-02721215}

Submitted on 1 Jun 2020

HAL is a multi-disciplinary open access archive for the deposit and dissemination of scientific research documents, whether they are published or not. The documents may come from teaching and research institutions in France or abroad, or from public or private research centers.
L'archive ouverte pluridisciplinaire HAL, est destinée au dépôt et à la diffusion de documents scientifiques de niveau recherche, publiés ou non, émanant des établissements d'enseignement et de recherche français ou étrangers, des laboratoires publics ou privés.

$$
\text { Copyright }
$$


Phytochemistry, Vol. 22, No. 4, pp. 841-847, 1983. Printed in Great Britain.

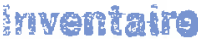

PU -376
$0031-9422 / 83 / 040841-07 \$ 03.00 / 0$

(C) 1983 Pergamon Press Ltd

\title{
COMPOSITION OF CELL WALLS FROM COTYLEDONS OF PISUM SATIVUM, VICIA FABA AND GLYCINE MAX
}

\author{
JeAN-Marc Brillouet and Bernard CARré
}

Institut National de la Recherche Agronomique, Centre de Recherches Agro-Alimentaires, Laboratoire de Biochimie et Technologie des Glucides, rue de la Géraudière, 44072 Nantes Cédex, France

(Revised received 13 September 1982)

Key Word Index - Pisum sativum; Vicia faba; Glycine max; Leguminosae; pea; broad bean; soya bean; cotyledons; cell walls; pectic substances.

\begin{abstract}
Cell walls from cotyledons of smooth field pea, broad bean and soya bean contain ca $55 \%$ pectic polysaccharides associated with $9 \%$ cellulose. Arabinose is the major pectic sugar of pea and broad bean walls whereas soya bean pectic polymers are constituted of galactose and arabinose in the ratio (2:1). Galacturonic acid represents $c a$ $20 \%$ of the walls. In addition, pea and broad bean cell walls contain, respectively, $12 \%$ and $6 \%$ of non-starchy and noncellulosic glucans bearing 4,6-linked and 3-linked glycosyl units. EDTA-soluble acidic pectic substances are distinct rhamnogalacturonans bearing decreasing proportions of interrupting rhamnose from highly interrupted moieties to nearly homogenous homogalacturonans. Pea and broad bean rhamnogalacturonans are associated with arabinosecontaining polymers of average DP $\mathrm{ca} 30-35$ whereas soya bean ones have side chains of arabinose and galactose of DP ca 40 .
\end{abstract}

\section{INTRODUCTION}

Legume seeds have been used since very ancient times as human food. They have the highest protein content of all edible plant materials and could constitute a good source of protein and starch for industrial technological transformations leading to processed products for human and animal consumption. The cytoplasmic components of cells (starch, protein, lipids) from legume seed kernel have been extensively studied whereas the cell wall constituents have been little studied largely because they are highly insoluble and thought to be indigestible by endogenous mammalian intestinal enzymes.

Major works in this field have been carried out on tropical and subtropical pulse crops such as groundnut or soya bean $[1,2]$. The seeds of temperate legumes have received little attention until rather recently when the involvement of cell wall material as a dietary fibre in the human diet has focused interest on the cell wall components from legume seeds.

Very recently, Reichert [3] isolated cell walls from dehulled pea flour and provided a complete quantitation of the material as classes of polysaccharides (pectic substances, hemicelluloses and cellulose). Neverthelèss, the monosaccharide constituents of the polysaccharides were not analysed and no structural information was provided. The other temperate climate grown pulse which has been under fairly detailed study is the broad bean $[4,5]$. Hemicelluloses A and B were extracted by alkali from dehulled seed flour and hemicellulose B was shown to be mainly built-up of glucosyl and xylosyl units. Glucose has also been detected as a major component of non-starchy water-soluble polysaccharides from broad bean cotyledons [6].

The purpose of the present investigation was to develop a detailed enzymic procedure for the preparation of cell wall material from cotyledons of field smooth pea (Pisum sativum L.), broad bean (Vicia faba var. minor L.) and, for comparative purposes, soya bean (Glycine $\max \mathrm{L}$.), a major legume fodder crop. The cell walls were analysed for all their constituents and the constitutive pectic substances, extracted by a chelating agent (EDTA), were characterized. In addition, water-soluble non-starchy polysaccharides, solubilized during cell wall preparation, were also considered.

\section{RESULTS AND DISCUSSION}

\section{Preparation of purified cell walls}

Finely ground solvent-extracted cotyledon meal was treated successively with pronase and a highly purified $\alpha$ amylase after starch gelatinization. The efficiency of hydrolysis of intracellular protein bodies by pronase was followed by measuring 10\% TCA-soluble amino acids and oligopeptides liberated by the protease [7]. After the first hydrolysis step, the removal of cytoplasmic protein was essentially complete as confirmed by the virtual absence of globular elements stained green by Fast Green colouring agent under the light microcope; except for cell walls which were faintly stained. A second pronase treatment was applied to ensure the complete removal of any traces of cytoplasmic proteins.

The yields and compositions of water-soluble nonstarchy polysaccharides solubilized during pronase treatment are indicated in Table 1. Arabinose was the major sugar constituent in the case of pea and broad bean, followed by galactose, galacturonic acid, glucose and minor amounts of rhamnose, mannose and xylose. The arabinose-galactose ratios (1:0.7-0.9) were very close to those observed in water extracts from seeds of the Phaseolus genus [8-10]. Soya bean soluble polysaccharides exhibited a similar qualitative constitution with an opposite arabinose-galactose ratio $(1: 1.6)$ corresponding to previous observations $[11,12]$. The mannose contents 
Table 1. Yield and composition of water-soluble non-starchy polysaccharides from studied legume seed cotyledons

\begin{tabular}{lcccccccccc}
\hline & \multicolumn{8}{c}{ Polysaccharide sugars (mol anhydropolymeric form/mol } \\
anhydroarabinose)
\end{tabular}

* Expressed as polysaccharidic material.

† Galacturonic acid determined colorimetrically.

$\ddagger$ Not determined.

were low indicating trace amount of endospermic galactomannans.

Starch, the other major intracellular compound in the case of pea and broad bean, was efficiently eliminated from deproteinized flours by a short gelatinization step followed by an $\alpha$-amylolysis. Pea, broad bean and soya bean (trace component) starches are known to gelatinize irreversibly in the temperature range of $62-81^{\circ}[13,14]$. As a consequence, the temperature for the gelatinization step $\left(85^{\circ}\right)$ was kept just above the upper limit for a short time (10 $\mathrm{min})$ in order to reduce possible thermal degradations of acidic cell wall polysaccharides [15] which are likely to occur during the prolonged boiling water gelatinization usually practised prior to amylolysis [16-18]. It must be noted that a perfect dispersion of the flour during gelatinization in hot water must be achieved in order to prevent the formation of clumps which will not undergo gelatinization and further amylolysis. The time course of starch hydrolysis by the highly purified $\alpha$-amylase was followed by measuring reducing sugars [19]. Completion of starch removal after $2 \mathrm{hr}$ was carefully checked by the iodine-potassium iodide staining test: neither native or damaged starch granules nor gelatinized amorphous material stained blue by iodine reagent were visible. Nevertheless, even after the second amylolysis treatment, minute amounts ( $\mathrm{ca} 2 \%$ of the walls) of undetected starch were measured by the DMSO-amyloglucosidase method [20] which corresponds to a hydrolysis efficiency higher than $99 \%$ Glucose obtained by TFA hydrolysis (see Table 2) was corrected for this residual starch.

The yields (Table 2) of cell walls from pea and broad bean were quite similar $(\mathrm{ca} 7 \%$ ) and almost identical to the previously reported yield $(6.9 \%)$ [3] from wet sieved dehulled pea flour. It is noteworthy that these two seeds belonging to the same Vicieae tribe [21] gave very close wall contents as opposed to soya bean from the Glycineae which was richer in cell wall material $(\mathrm{ca} 9 \%)$ and comparable to groundnut endosperm ( $\mathrm{ca} 10 \%$ ) [1].

\section{Composition of cell walls}

The chemical compositions of the three purified cell wall preparations are indicated in Table 2 . As with other plant cell walls $[22,23]$, these walls were composed mainly of non-starchy polysaccharides which accounted respectively for $\mathrm{ca} 82 \%, 83 \%$ and $73 \%$ of the walls. Noncarbohydrate matter was composed of pronase-resistant wall protein, phenolics and minerals.

The protein levels were somewhat lower as compared to those observed in wet sieved pea cell walls $(\mathrm{ca} 5 \%$ ) [3] and in pronase-glucoamylase treated groundnut flour (ca $7 \%$ ) [1].

The lignin contents were estimated by the acetyl bromide procedure $[23,24]$ and UV spectra were recorded in the range $250-340 \mathrm{~nm}$. The three walls gave a similar response characterized by a maximum at $260-264 \mathrm{~nm}$ with a shoulder at $310-320 \mathrm{~nm}$ indicating unambiguously the presence of some lignified material in the cell wall preparation [25]. They were poorly lignified ( $\mathrm{ca} 2-3 \%$ ) as opposed to strongly lignified ( $\mathrm{ca} 11 \%$ ) in the case of cell wall material obtained by wet sieving of pea flour [3]. Light microscopy confirmed this low lignin content by showing that lignin was exclusively located in very scarce vascular bundles which were stained strongly pink by phoroglucinol reagent [26] whereas parenchyma

Table 2. Yield and composition of cell walls from studied legume seed cotyledons

\begin{tabular}{|c|c|c|c|c|c|c|c|c|c|c|c|c|}
\hline \multirow[b]{2}{*}{ Species } & \multirow{2}{*}{$\begin{array}{c}\text { Yield* } \\
(\%)\end{array}$} & \multicolumn{7}{|c|}{ Polysaccharide sugars (anhydropolymeric, $\%$ ) $\dagger$} & \multirow{2}{*}{$\begin{array}{c}\text { Protein } \\
(\%)\end{array}$} & \multirow{2}{*}{$\begin{array}{c}\text { Lignin } \\
(\%)\end{array}$} & \multirow{2}{*}{$\begin{array}{c}\text { Minerals } \\
(\%)\end{array}$} & \multirow{2}{*}{$\begin{array}{c}\text { Total } \| \\
(\%)\end{array}$} \\
\hline & & GalA $\S$ & Rha & Fuc & Ara & Xyl & Gal & Glc & & & & \\
\hline Smooth field pea & 6.9 & 15.3 & $(1.6) \ddagger$ & 0.7 & 35.0 & 3.7 & 4.4 & $21.2(12.1) \ddagger$ & 1.4 & 2.5 & 0.4 & 86.2 \\
\hline Broad bean & 7.2 & 19.8 & (1.9) & 0.8 & 36.1 & 3.4 & 3.9 & $17.2(6.2)$ & 1.2 & 3.0 & 0.4 & 87.7 \\
\hline Soya bean & 9.3 & 16.5 & $(1.3)$ & 2.3 & 13.2 & 3.8 & 25.4 & $10.2(1.1)$ & 2.5 & 3.7 & 0.8 & 79.7 \\
\hline
\end{tabular}

* Percent on dry wt basis.

$\dagger$ Mean from Saeman and TFA hydrolysis values.

$\ddagger$ Rhamnose and glucose from TFA hydrolysis.

§Galacturonic acid determined colorimetrically.

||Glucose from Saeman hydrolysis and rhamnose from TFA hydrolysis taken into account. 
cell walls remained unstained. As a consequence, cotyledon cell walls from the three seeds were thought to be of a primary cell wall-like type [22] contrary to the secondary lignified tissue reported by Reichert [3] in pea cotyledons.

This statement was supported by the polysaccharidic compositions which were characteristic of dicotyledonous primary cell walls [22] by being mainly constituted of arabinose, galactose and galacturonic acid as the major non-cellulosic pectic sugars. Smooth pea and broad bean cell walls presented rather similar carbohydrate constitutions, arabinose being present in major amounts, followed by minor quantities of galactose, xylose, rhamnose and fucose. Similar findings were obtained on sycamore [22] and kidney bean primary walls from cells grown in suspension culture [27] as well as on groundnut endosperm cell walls [1]. It must be noted that the xylose content of our preparations was very low which is indicative of perfect hand dehulling since legume hulls are known to contain large amounts of xylan as hemicellulosic polymers [28, 29].

On the other hand, soya bean cotyledon cell walls had a very different polysaccharide composition, galactose being the major sugar constituent, followed by arabinose and minor amounts of xylose, rhamnose and fucose.

Uronic acid, which was presumed to be essentially of the galacturonic type since it was associated with the pectic sugars arabinose, galactose and rhamnose [22], was also an important component of the cell walls of pea, broad bean and soya bean yielding equivalent amounts $(15-20 \%)$. These figures were comparable to values obtained on suspension cultured sycamore cell walls $(\mathrm{ca} 13 \%$ ) [22].

The values for glucose contents obtained from TFA and Saeman hydrolyses are given in Table 2. TFA hydrolysis $[30,31]$ is known to hydrolyse a few percent of the cellulose, whereas Saeman hydrolysis liberates the bulk of the cellulosic glucose. In the case of soya bean cell walls, glucose obtained by TFA hydrolysis was rather low (ca $11 \%$ of total determined glucose) and could correspond to partially hydrolysed amorphous cellulose moieties. In contrast, smooth field pea and broad bean gave rather large amounts of glucose on TFA treatment ( $57 \%$ and $36 \%$, respectively of total glucose), the pea walls being richer ( $\mathrm{ca} 12 \%$ ) than broad bean ( $\mathrm{ca} 6 \%$ ). Even if some of the TFA-liberated glucose originated from amorphous cellulose most of it must be of noncellulosic glucan origin. As mentioned, correction for residual contaminating starch has been applied to TFAhydrolysable glucose. Methylation analysis of cell wall glucose polymers has shown that amongst glucose methyl ethers, respectively, $7 \%$ and $14 \%$ were recovered in the 2,3-di-O-methyl ether form for pea and broad bean which revealed branching through C-6 of cellulose-like backbones and may be indicative of a xyloglucan structure [32]. Moreover, the 2,4,6-tri-O-methyl ether accounted for, respectively, $5 \%$ and $7 \%$ of the total glucose and corresponded to $(1 \rightarrow 3)$ glycosyl linkages. Nonstarchy and non-cellulosic glucosans have been frequently observed in legume seed cotyledons $[6,18,33-35]$ as well as in suspension-cultured dicotyledonous primary cell walls $[22,27]$. In this latter case $[22]$, a rough proportional equivalence was proposed between xyloglucan and cellulose in the cell wall. In conclusion, field pea and broad bean native flours contained $0.8 \%$ and $0.4 \%$, respectively, of hot water insoluble non-starchy and non-cellulosic glucose polymers bearing 4,6-linked and 3-linked glucosyl units in addition to 4-linked glucose.

Assuming that a rather good estimation of cellulose is provided by the difference between glucose obtained from Saeman and TFA hydrolyses [31], it must be pointed out that the cell walls contained rather similar amounts ( $\mathrm{ca} 9 \%$ ) of cellulose which corresponds, respectively, to $0.6 \%, 0.8 \%$ and $0.8 \%$ of cotyledon dry matter of pea, broad bean and soya bean. Our cellulose figures were comparable to the $\alpha$-cellulose content expressed as glucose $(\mathrm{ca} 0.8 \%)$ of dehulled tora bean [36] and somewhat lower than those obtained on groundnut (ca $5 \%$ ) $[1]$ and winged bean $(\mathrm{ca} 3 \%)[18]$ by alkali extraction of non-cellulosic material. The occurrence of xyloglucan and arabinoglucan moieties in $24 \%$ potassium hydroxide insoluble material from Phaseolus vulgaris cotyledons [36] tends to indicate that cellulose determinations based on strong alkali extractions $[37,38]$ could overestimate the true cellulose content as opposed to an estimation based on the difference of glucose content from strong and dilute acid hydrolyses [31].

As shown in Table 2, the recoveries $(80-90 \%)$ were rather good for three legumes studied.

\section{Extraction and characterization of pectic substances from} purified cell walls.

Pectic substances were extracted by hot EDTA according to Aspinall et al. [2] and represented ca 44\%,53\% and $50 \%$ of starting cell walls as determined by colorimetric analysis of acidic and neutral sugars. Quantitation of neutral moieties by the orcinol method was improved by taking into account the various adsorbances of monosaccharide constituents preliminarily determined by GC (Table 3). The total EDTA-soluble pectic substances from each cell wall preparation presented a similar neutral-acidic sugar ratio ( $c$ a 2.5-3), galacturonic acid constituting $25 \%$ of the polysaccharidic material, which is comparable to previously reported data on soya bean [2]. Pectic substances from smooth field pea and broad bean cell walls exhibited similar neutral monosaccharide constitutions, arabinose being present in major amounts followed by minor quantities of xylose, galactose, glucose and rhamnose. On the other hand, soya bean walls contained pectic substances rich in galactose and arabinose in a molar ratio of $1.5: 1$. The galacturonic acid-rhamnose ratios were almost identical (ca 12) for pea and broad bean and higher than in soya bean cell walls (ca 8). Those figures were somewhat higher than in suspension-cultured sycamore primary cell walls ( $\mathrm{ca} 4$ ) [22].

The pectic substances were submitted to ion exchange chromatography on DEAE-Sepharose CL-6B (Fig. 1). Unbound neutral material represented, respectively, $10.6 \%, 13.5 \%$ and $6.3 \%$ of total pectic substances of pea, broad bean and soya bean. The three neutral fractions eluted between void and total volume at very similar elution volumes $(55-60 \mathrm{ml})$ indicating rather low MWs. Pea and broad bean neutral polysaccharides exhibited almost identical compositions (Table 3), arabinose being the major sugar constituent followed by minor quantities of glucose and galactose. Although no structural analysis was performed, these neutral pectic polymers, due to their composition, were thought to be of the arabinan type which are of frequent occurrence in legume seeds from the Papilionoideae sub-family $[12,39,40]$. On the other hand, 


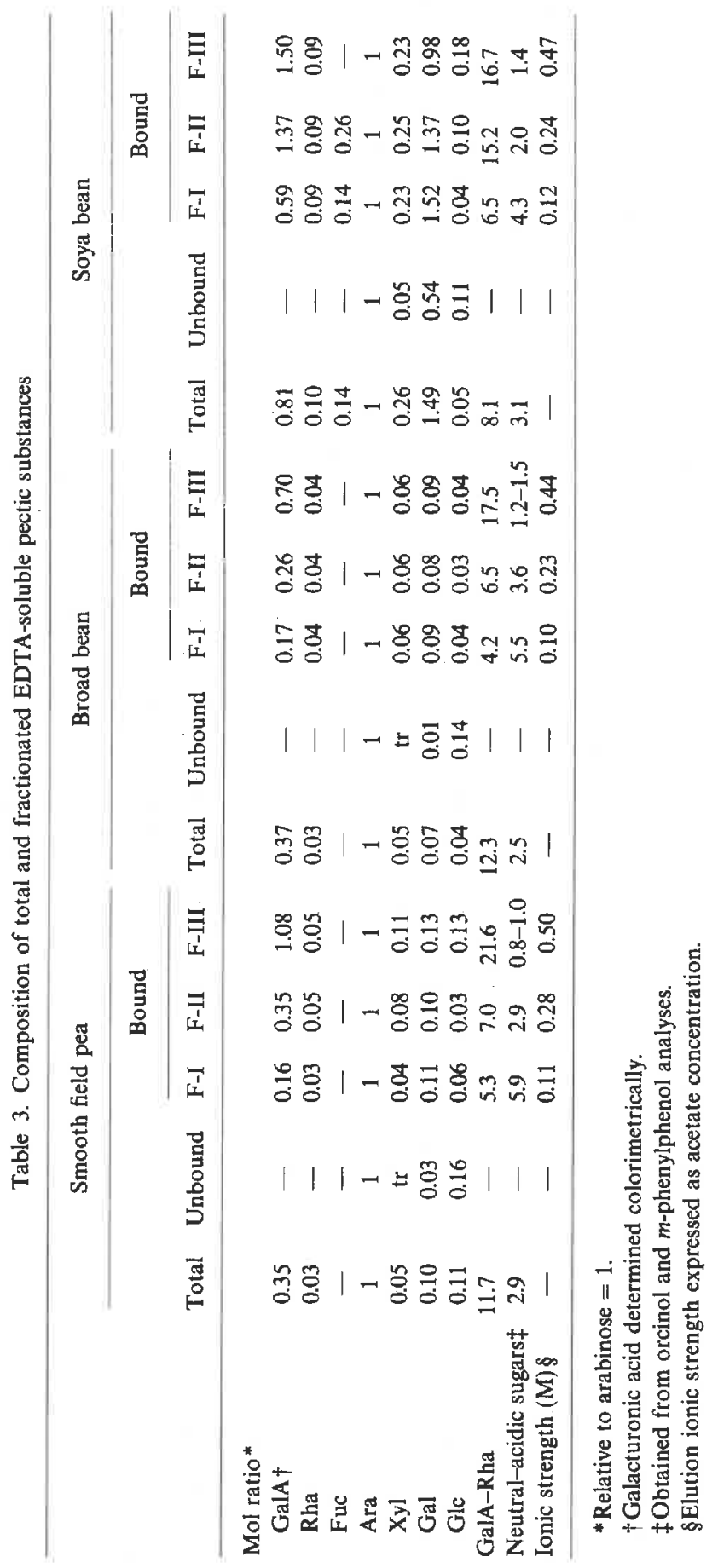




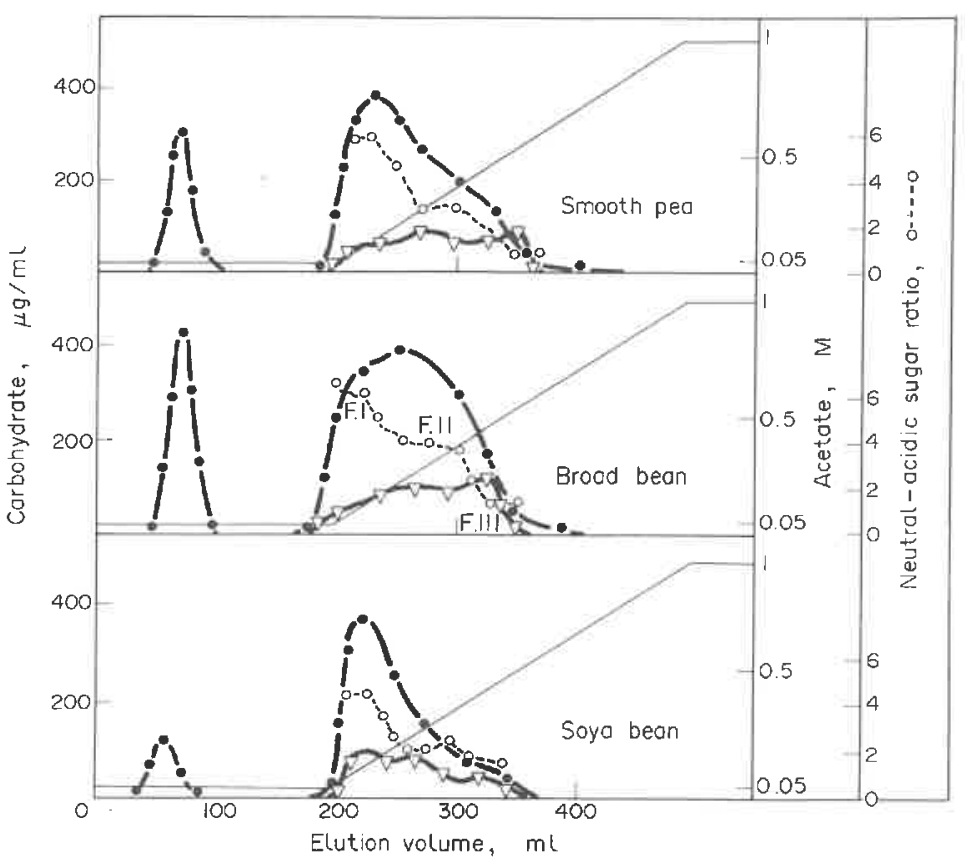

Fig. 1. Ion-exchange chromatograms of EDTA-soluble pectic substances from cotyledon cell walls of pea, broad bean and soya bean on DEAE-Sepharose CL-6B $(13 \times 3.2 \mathrm{~cm})$. After sample loading $(\mathrm{ca} 70 \mathrm{mg})$, the column was extensively washed with $0.05 \mathrm{M} \mathrm{NaOAc}$ buffer, $\mathrm{pH} 4.8$, after which bound polysaccharides were eluted by a linear sodium acetate gradient $(0.05-1 \mathrm{M} ; 300 \mathrm{ml})$. Collected fractions were analysed for neutral $(\bullet)$ and acidic $(\nabla)$ sugars, and the neutral-acidic sugar ratio $(O)$ determined.

soya presented a different constitution, arabinose being accompanied by significant amounts of galactose and glucose. Aspinall and Cottrell [12] have shown that neutral pectic polysaccharides of soya bean cotyledons are constituted of equivalent amounts of an arabinan and an arabinogalactan (gal-ara $=2.8$ ).

Bound acidic pectic polysaccharides were eluted by a linear acetate gradient $(0.05-1 \mathrm{M})$ as complexes which seemed at first sight to be very different from one another, the broad bean complex being richer in neutral covalently linked sugars than the pea and soya bean complexes. At least three distinct polysaccharidic populations, eluting, respectively, at ca 0.10 (F-I), 0.25 (F-II) and $0.5 \mathrm{M}$ (F-III) ionic strength (Table 3 ) could be distinguished for the three legume seeds. The elution patterns of galacturonic acid were quite similar for pea and broad bean, the middle fraction, F-II, being the major one followed by equivalent amounts of side fractions F-I and F-III as roughly determined by visual estimation of the peaks. The soya bean acidic complex exhibited different distribution, F-I and F-II being equivalent whereas F-III was present in minor amount. The existence of three pectic moieties was supported by the variation of neutral-acidic sugar ratio (Table 3) along the chromatograms, showing three levels. The most weakly bound fraction (F-I) exhibited, as expected, the highest ratio, the pea (5.9) and broad bean (5.5) ones being rather similar and higher than that of soya bean (4.3). Fraction F-II which was eluted at higher ionic strength gave a lower ratio from 2 to 3.6. Finally, the most strongly bound fraction (F-III) exhibited a rough weight equivalence between galacturonan and associated neutral polymers (0.8-1.5). In terms of recoveries, $90-100 \%$ yields were obtained for neutral moieties (unbound + bound fractions), whereas galacturonic acid was recovered in $50-60 \%$ yield for pea and broad bean and $70 \%$ for soya bean. Raising the ionic strength up to $2 \mathrm{M}$ acetate failed to remove strongly adsorbed acidic material which must be essentially of the homogalacturonan type since it was essentially devoid of associated neutral sugars (F-IV). The compositions of fractions F-I-F-III indicated that neutral polymers, associated with rhamnogalacturonans from pea and broad bean, exhibited very close monosaccharide constitutions, except for F-III from pea which was richer in xylose and glucose. The pectic fractions from soya bean contained smaller amounts of galactose relative to arabinose whilst the galacturonic acid content increased from F-I to F-III. The galacturonic acid-rhamnose ratio which is significant of the 'interrupted' character of rhamnogalacturonans $[41]$ increased from $4-6(\mathrm{~F}-\mathrm{I})$ to 17-22 (F-III) with intermediate values (7-15) for F-II. It must be noted that the neutral-acidic sugar ratio decreased inversely.

The cell wall preparations from cotyledons of the legume seeds under study exhibited some general structural features in common. The rhamnogalacturonan constituent exists as several distinct forms constituting a discontinuous structure bearing galacturonan moieties with decreasing proportions of interrupting rhamnosyl units (F-I $\rightarrow$ F-IV). Whether the rhamnogalacturonans were non-covalently linked inside the cell wall depends on the extent of degradation due to hot EDTA extractions at $\mathrm{pH}$ 5.0. However, the conditions described by Aspinall et al. [2] and generally used for pectic substance extraction are thought to be non-hydrolytic even on labile $\alpha$ arabinofuranosidic linkages. Therefore, the emergence of at least four acidic fractions from legume seed cell walls 
cannot be a hydrolysis artifact unless they were produced by a $\beta$-elimination mechanism [15]. This discontinuous pattern is inconsistent with the unique rhamnogalacturonan molecule described previously [22] for sycamore primary cell walls. The neutral sugar-rich galacturonan portion (hairy region) [22] or rhamnogalacturonan I [42] produced by endopolygalacturonase action on sycamore walls (galA-rha $=2$ ) can be compared with F-I, whereas the homogalacturonan fraction [22] may be related to $\mathrm{F}$ III and F-IV. Preliminary methylation experiments have shown that $c a 66 \%$ of cell wall rhamnose was 2,4-linked [Brillouet, J.-M., unpublished work]. Assuming that branching of neutral side chains occurred essentially on C-4 of rhamnosyl units $[22,42]$, a mean DP of $30-35$ could be calculated for neutral polymérs, associated with acidic moieties from pea and broad bean, whereas a DP of ca 40 was obtained for soya bean. These figures are of the same magnitude as degrees of polymerization reported for the free arabinan II (DP = 34) from Rosa glauca [43] and for the galactan (DP $=33$ ) of white willow [44] and considerably higher than the average side chain length $(D P=6)$ reported for rhamnogalacturonan I of sycamore primary cell walls [42]. Furthermore, similarity of neutral sugar compositions of F-I-F-III for pea and broad bean suggested a structural uniformity of side chains branched on various rhamnogalacturonan moieties. On the other hand, soya bean side chains presented some compositional fluctuations indicative of structural variations, probably induced by superimposition of additional galactose-containing polymers [Carré, B., personal communication].

\section{EXPERIMENTAL}

Legume seed samples. Smooth pea (Pisum sativum L., cv Amino) and broad bean (Vicia faba var. minor, cv Ascott) were kindly provided by the Station d'Amélioration des Plantes, I.N.R.A. (Dijon, France). Soya beans (Glycine max L.) were obtained from Grand Blottereau tropical greenhouses (Nantes, France). Seeds were first cracked between rollers and then dehulled by a HEF dehuller (Hydrodynamique et Frottement, Saint-Etienne, France). Remaining traces of hull were carefully eliminated with tweezers and the germ was cut off from cotyledons with a razor blade. Hand-dissected cotyledons were ground in a tap $\mathrm{H}_{2} \mathrm{O}$ refrigerated grinder for no longer than $15 \mathrm{sec}$. Seed meals were then sieved through a $0.5 \mathrm{~mm}$ screen.

Chemicals. $\alpha$-Amylase from Bacillus subtilis (EC 3.2.1.1., Type II-A, $1000 \mathrm{U} / \mathrm{mg}$ ) was purchased from Sigma (U.S.A.). Pronase from Streptomyces griseus $(6 \mathrm{U} / \mathrm{mg})$ was obtained from Boehringer Mannheim (West Germany). $m$-Phenylphenol was from Eastman Kodak (U.S.A.); kraft lignin Indulin was obtained from Westvaco (U.S.A.). All other reagents were of an analytical grade.

Preparation of purified cotyledon cell walls. Native seed meals were exhaustively extracted using a Soxhlet apparatus with, successively, $\mathrm{CHCl}_{3}, \mathrm{MeOH}$ and $\mathrm{Me}_{2} \mathrm{CO}$. Defatted seed meal $(100 \mathrm{~g})$ was then soaked in $980 \mathrm{ml} 0.1 \mathrm{M} \mathrm{Pi}$ buffer, pH 7.5, containing $0.02 \% \mathrm{NaN}_{3}$ as bactericide. The suspension was homogenenized with a Polytron homogenizer $(2 \mathrm{~min})$ and transferred into a jacketed cuvette maintained at $30^{\circ}$. Enzymic hydrolysis was started by addition of pronase $(250 \mathrm{mg} / 20 \mathrm{ml}$ of $0.1 \mathrm{M}$ Pi buffer, $\mathrm{pH}$ 7.5) under continuous stirring. Proteolysis was followed by measuring 10\% TCA-soluble amino acids and peptides released by pronase [7]. After $20 \mathrm{hr}$ hydrolysis, the suspension was centrifuged. Then the pellet was retreated under the same conditions using $125 \mathrm{mg}$ pronase for the second hydrolysis. The white deproteinized residue was recovered by centrifugation, copiously washed with $\mathrm{H}_{2} \mathrm{O}$ and dried. The supernatants from the first and second hydrolyses were pooled, concd $(\times 10)$ under vacuum at $40^{\circ}$, refrigerated at $4^{\circ}$ and solid TCA added to a final concn of $10 \%$. After centrifugation, the supernatant was extensively dialysed against $\mathrm{H}_{2} \mathrm{O}\left(4^{\circ}\right)$ and mixed with 5 vol. EtOH. The resulting ppt was collected by centrifugation, washed with $83 \% \mathrm{EtOH}$ and dried.

Pronase-treated meal $(100 \mathrm{~g})$ was then suspended with violent stirring in $2 \mathrm{l} . \mathrm{H}_{2} \mathrm{O}$ at $85^{\circ}$ and starch gelatinization was allowed to proceed for $10 \mathrm{~min}$. Then the temp. of the viscous suspension was rapidly adjusted to $50^{\circ}$ and $500 \mathrm{ml} 0.1 \mathrm{M} \mathrm{NaOAc}$ buffer, $\mathrm{pH} 5.6$, was added. Starch enzymic hydrolysis was initiated by adding $\alpha-$ amylase $(150 \mathrm{mg} / 25 \mathrm{ml} 0.02 \mathrm{M}$ NaOAc buffer, $\mathrm{pH} 5.6)$ under continuous stirring. The time course of starch hydrolysis was followed by measuring reducing sugars [19] on aliquots. After $2 \mathrm{hr}$ hydrolysis, the suspension was centrifuged and the pellet was retreated under the same conditions using $75 \mathrm{mg} \alpha$-amylase for the second hydrolysis. The white deproteinized and destarched residue (purified cell walls) was recovered by centrifugation, thoroughly washed with $\mathrm{H}_{2} \mathrm{O}$ and dried. Both supernatants, treated under same conditions as above (pronase treatment), gave no ppt when mixed with 5 vol. EtOH.

Cell walls $(100 \mathrm{~g})$ were extracted with $2 \%$ EDTA $\mathrm{Na}_{2}$ salt, $\mathrm{pH} 5.0$, for $4 \mathrm{hr}$ at $100^{\circ}$ [2]. The residue was separated by centrifugation and retreated $(\times 3)$ with hot EDTA under the same conditions as above. After centrifugation, the pellet was copiously washed with $\mathrm{H}_{2} \mathrm{O}$ and dried. The supernatants from successive extractions were pooled, concd and extensively dialysed against $\mathrm{H}_{2} \mathrm{O}$ prior to analysis.

Analytical methods. Moisture determination was carried out by heating samples at $130^{\circ}$ for $2 \mathrm{hr}$; all yields and compositions are given on a moisture free basis.

Cell wall $\mathrm{N}$ was determined by a micro-Kjeldahl procedure and converted into protein using a conversion factor of 5.8. Lignin was analysed by a slightly modified acetyl bromide procedure $[23,24]$ : alkali labile phenolics bound to the lignin core were eliminated by treating cell walls with $1 \mathrm{M} \mathrm{NaOH}$ for $24 \mathrm{hr}$ at $20^{\circ}$; then lignin measurement was carried out in the usual way using a kraft lignin as a standard.

Cell wall polysaccharides from purified cotyledon cell wall were hydrolysed according to Saeman et al. [45] $\left(72 \% \mathrm{H}_{2} \mathrm{SO}_{4}\right.$, $20^{\circ}, 2 \mathrm{hr}$, then dilution to $1 \mathrm{M}, 100^{\circ}, 2.5 \mathrm{hr}$ ) or with $2 \mathrm{M}$ trifluoroacetic acid (TFA) at $120^{\circ}$ for $1.25 \mathrm{hr}$ [29], whereas soluble polysaccharidic fractions were hydrolysed by TFA. Individual monosaccharides were converted to their alditol acetates [46] and analysed by GC on a column $(180 \times 0.2 \mathrm{~cm})$ of $3 \%$ SP 2340 coated on Supelcoport (100-120 mesh) at $225^{\circ}\left(\mathrm{N}_{2}\right.$ : $20 \mathrm{ml} / \mathrm{min}$ ) using inositol as int. standard.

Uronic acids were analysed by the $m$-phenylphenol method [47] using galacturonic acid as standard; purified cotyledon cell walls were treated with conc $\mathrm{H}_{2} \mathrm{SO}_{4}$ prior to analysis [48].

Purified cell walls as well as ppted soluble fractions were dried by solvent exchange through $\mathrm{EtOH}, \mathrm{Me}_{2} \mathrm{CO}$ and $\mathrm{Et}_{2} \mathrm{O}$. Unless otherwise stated, centrifugations were carried out at $18000 \mathrm{~g}$ for $20 \mathrm{~min}$ at room temp.

Minerals were determined by the $\mathrm{X}$-ray dispersive microanalysis system [49].

Chromatographic methods. EDTA-extracted pectic substances were submitted to ion-exchange chromatography on DEAESepharose CL-6B (Pharmacia) columns $(13 \times 3.2 \mathrm{~cm})$ equilibrated by $0.05 \mathrm{M}$ NaOAc buffer, $\mathrm{pH} 4.8$ [50]. Pectic substances (ca 60-70 mg) were adsorbed on the exchanger, and the column was eluted with $0.05 \mathrm{M} \mathrm{NaOAc}$ buffer, $\mathrm{pH} 4.8$. Bound polysaccharides were eluted with a linear $\mathrm{NaOAc}$ gradient $(300 \mathrm{ml})$ at $\mathrm{pH}$ $4.8(0.05-1 \mathrm{M})$. Fractions $(6 \mathrm{ml})$ were collected and analysed 
automatically for their galacturonic acid and neutral sugars contents by the $m$-phenylphenol [51] and orcinol [52] methods, respectively, with correction for mutual interference and individual response of constituent sugar units. Appropriate fractions were pooled, extensively dialysed against $\mathrm{H}_{2} \mathrm{O}$ and analysed for their monosaccharide contents by $\mathrm{GC}$ as described in the analytical methods.

Methylation analysis of cell wall glucose containing polymers. Pea and broad bean cell walls were permethylated $(\times 3)$ according to ref. [53]. Fractions soluble in $\mathrm{CHCl}_{3}-\mathrm{MeOH}(1: 1)$ (ca $80 \%$ of starting cell walls) were hydrolysed, alditol acetate derivatized and partially methylated alditol acetates analysed by GC/MS [54] for the glucosyl $O$-methyl ethers.

Light microscope examinations. Purified cell wâlls were observed under a light microscope using Fast Green colouring agent for examination of protein bodies, $\mathrm{I}_{2}-\mathrm{KI}$ for starch and phloroglucinol reagent for lignified elements [25].

Acknowledgement-We wish to thank the tropical greenhouses of Grand Blottereau (Nantes, France) for a gift of soya bean seeds.

\section{REFERENCES}

1. Tharanathan, R. N., Wankhede, D. B. and Raghavendra Rao, M. R. R. (1975) J. Sci. Food Agric. 26, 749.

2. Aspinall, G. O., Begbie, R., Hamilton, A. and Whyte, J. N. C. (1967) J. Chem. Soc. C 1065.

3. Reichert, R. D. (1981) Cereal Chem. 58, 266.

4. Kawamura, S. and Narasaki, T. (1956) Bull. Agric. Chem. Soc. Jpn. 20, 289.

5. Kawamura, S. and Narasaki, T. (1958) Bull. Agric. Chem. Soc. Jpn. 22, 436

6. Pritchard, P. J., Dryburgh, E. A. and Wilson, B. J. (1973) J, Sci. Food Agric. 24, 663.

7. Saunders, R. M. and Kohler, G. O. (1972) Cereal Chem. 49, 98.

8. Chakraborty, A. K. (1975) J. Indian Chem. Soc. 52, 172.

9. Susheelamma, N. S. and Rao, M. V. L. (1978) J. Agric. Food Chem. 26, 1434.

10. Sathe, S. K. and Salunkhe, D. K. (1981) J. Food Sci. 46, 1276

11. Morita, M. (1965) Agric. Biol. Chem. 29, 564.

12. Aspinall, G. O. and Cottrell, I. W. (1971) Can. J. Chem. 49, 1019.

13. Vose, J. R. (1977) Cereal Chem. 54, 1141.

14. Wilson, L. A., Birmingham, V. A., Moon, D. P. and Snyder, H. E. (1978) Cereal Chem. 55, 661.

15. Albersheim, P., Neukom, H. and Deuel, H. (1960) Arch. Biochem. Biophys. 90, 46.

16. Cerning, J., Saposnik, A. and Guilbot, A. (1975) Cereal Chem. 52, 125 .

17. Anderson, N. E. and Clydesdale, F. M. (1980) J. Food Sci. 45 , 336.

18. Umadevi Sajjan, S. and Wankhede, D. B. (1981) J. Food Sci. 46, 601 .

19. Nelson, N. (1944) J. Biol. Chem. 153, 375.

20. (1978) Boehringer Mannheim, West Germany, Analytical Bulletin No. 776. 6354.

21. Heywood, V. H. (1971) in Chemotaxonomy of the Leguminosae (Harborne, J. B., Boulter, D. and Turner, B. L., eds.) pp. 1-29. Academic Press, London.

22. Talmadge, K. W., Keegstra, K., Bauer, W. D. and Albersheim, P. (1973) Plant Physiol. 51, 158.
23. Selvendran, R. R. and DuPont, M. S. (1980) Cereal Chem. 57, 278.

24. Morrison, I. M. (1972) J. Sci. Food Agric. 23, 455.

25. Monties, B. and Rambourg, J.-C. (1978) Ann. Technol. Agric. 27,629 .

26. Locquin, M. and Langeron, M. (1978) in Manuel de Microscopie (Masson, ed.) Masson, Paris.

27. Baker, C. J., Whalen, C. H., Korman, R. Z. and Bateman, D. F. (1979) Phytopathology 69, 789.

28. Banerji, N. and Rao, C. V. N. (1963) J. Indian Chem. Soc. 40 , 941.

29. Aspinall, G. O., Hunt, K. and Morrison, I. M. (1966) J. Chem. Soc. C 1945.

30. Albersheim, P., Nevins, D. J., English, P. D. and Karr, A. (196.7) Carbohydr. Res. 5, 340.

31. Ring, S. G. and Selvendran, R. R. (1980) Phytochemistry 19 , 1723.

32. Bauer, W. D., Talmadge, K. W., Keegstra, K. and Albersheim, P. (1973) Plant Physiol. 51, 174.

33. Cerning-Beroard, J. and Filiatre, A. (1976) Cereal Chem. 53, 968.

34. Naivikul, O. and D'Appolonia, B. L. (1979) Cereal Chem. 56, 45 .

35. El-Hanafy, A. R. S. and Taha, M. I. (1963) J. Org. Chem. 28 , 1559.

36. Ohtani, K. and Misaki, A. (1980) Agric. Biol. Chem. 44, 2029.

37. Corbett, W. M. (1963) in Methods in Carbohydrate Chemistry (Whistler, R. L., ed.) pp. 27-28. Academic Press, New York.

38. A.O.A.C. (1975) in Official Methods of Analysis of the Association of Official Analytical Chemists (Horwitz, W. ed.) pp. 136-137. Association of Official Analytical Chemists, Washington.

39. Hirst, E. L. and Jones, J. K. N. (1947) J. Chem. Soc. 1221.

40. Ukai,'S., Hara, C., Kiho, T. and Hirose, K. (1978) Chem. Pharm. Bull. 26, 1729.

41. Albersheim, P. (1976) in Plant Biochemistry (Bonner, J. and Varner, J. E., eds.) pp. 225-274. Academic Press, New York.

42. McNeil, M., Darvill, A. G. and Albersheim, P. (1980) Plant Physiol. 66, 1128.

43. Joseleau, J.-P., Chambat, G., Vignon, M. and Barnoud, F. (1977) Carbohydr. Res. 58, 165.

44. Toman, R., Karacsonyi, S. and Kovacik, V. (1972) Carbohydr. Res. $25,371$.

45. Saeman, J. F., Moore, W. E., Mitchell, R. L. and Millet, M. A. (1954) Tappi 37, 336.

46. Sawardeker, J. F., Sloneker, J. H. and Jeanes, A. (1965) Analyt. Chem. 37, 1602.

47. Blumenkrantz, N. and Asboe-Hansen, G. (1973) Analyt. Biochem. 54, 484.

48. El Rayah Ahmed, A. and Labavitch, J. M. (1977) J. Food Biochem. 1, 361.

49. Colonna, P., Gallant, D. and Mercier, C. (1980) J. Food Sci. 45, 1629 .

50. Barbier, M. and Thibault, J.-F. (1982) Phytochemistry 21, 111.

51. Thibault, J.-F. (1979) Lebensm.-Wiss. Technol. 12, 247.

52. Tollier, M.-T. and Robin, J.-P. (1979) Ann.Technol. Agric. 28, 1.

53. Ring, S. G. and Selvendran, R. R. (1978) Phytochemistry 17, 745.

54. Jansson, P. E., Kenne, L., Liedgreen, H., Lindberg, B. and Lonngren, J. (1976) Chem. Commun. Unit. Stockholm No. 8. 
